\title{
Ігор Карівець
}

\section{ДЕКОНСТРУКЦІЯ ТА РЕКОНСТРУКЦІЯ ПОНЯТТЯ ДГ'ЯНА: СТРАТЕГІЇ ТА ПЕРСПЕКТИВИ.}

\section{Данилов, Д. (2020). Трансформація поняття «дг'яна» у вченні йоги. Київ: Дух і Літера.}

Не часто в українській академічній історико-філософській царині з'являються монографії, присвячені індійській філософії загалом чи окремим іiї підставовим поняттям, а $з$ історичною деконструкцією та реконструкцією - то й поготів.

Дмитро Данилов обрав для такої деконструкції та реконструкції йогічне поняття «дг'яна», тому його монографія - це монографія про історію одного поняття з багатьма змістами та значеннями. У світовій філософській літературі існує ціла низка тематично споріднених видань ${ }^{1}$.

Такий розмаїтий зміст і багатозначність не випадкові, адже будь-яке поняття будьякої філософії, релігії чи духовної практики має своє істинне значення лише в середовищах свого походження. Воно $є$ точним у тій філософії, релігії чи духовній практиці, які його породили, коли ж його перекладають іншими мовами чи «імплементують» в інші філософії, релігії або духовні практики, саме тоді з’являється «багатозначність»,

(C) I. Карівець, 2021

${ }^{1}$ На деякі видання, що безпосередньо стосуються історії понять філософії йоги та медитації, варто звернути увагу.

Монографією «одного індійського філософського поняття» є монографія Стюарта Рея Сарбейкера «Самадгі» [Sarbaker 2005]. Автор цієї монографії детально аналізує поняття «самадгі», не лише вписуючи його в історичний та соціально-культурний контекст, а й порівнюючи його вживання в індійській йозі та буддизмі. До речі, Дмитро Данилов також звертається до порівняння значень дг'яни в цих двох напрямах духовних практик [Данилов 2020: 115-116]. Він доходить висновку, що без врахування буддистського елементу в дг'яні ії зміст і значення були б неповними.

Книга «Сутри, оповіді, філософія йоги» Даніеля Равега присвячена детальному аналізові епічного твору «Магабгарата», сакральних текстів «Упанішад» та «Йога-сутри» Патанджалі задля виявлення зв'язку між оповіддю, філософією та істиною понять [Raveh 2016]. У ній цитуються слова індійського мислителя Дайя Крішни (Daya Krishna, 1924-2007), згідно з яким філософія - це «концептуальне мистецтво» [Raveh 2016: 1]. Дослідження Д. Данилова підтверджує, що поняття дг'яни має глибокий філософський зміст і може поглибити наше розуміння природи розуму, мислення, свідомості, одним словом, ментального життя людини.

Із найновіших закордонних досліджень індійської філософії та її «концептуального каркасу», одножанрових із дослідженням Дмитра Данилова, варто згадати фундаментальну книжку «Підручник з вивчення йоги та медитації» за редакцією Сузанни Ньюкомб та Карен О’Браєн-Коп [Newcombe, O’Brien-Kop 2020]. 
«неперекладність». Недарма назва монографії Д. Данилова містить слово «трансформація», яке вказує на переходи, зміщення значень поняття дг'яна, а також на переступання й навіть на подолання (витіснення) одних значень іншими. Віднайдення первинного змісту та значення поняття дг'яна, а також тих станів свідомості й переживань йогінів, яке воно означує, - такі завдання ставить перед собою Д. Данилов.

Розв'язання цих завдань потребує неабиякого знання концептуальних основ йогічної практики й санскриту. Автор монографії звертається до літератури, присвяченої не лише сформованому поняттю дг’яна, а й початкам такого формування. Д. Данилов аналізує першоджерела як дойогічної літератури, так і класичні (традиційні) йогічні трактати. Відтак автор чітко окреслює періоди трансформації поняття дг'яна в різні епохи становлення йоги, а саме: I-й період - ведичний: приблизно XVI ст. до н.е. - II ст. до н.е.; II-й період - епічний: II ст. до н.е. - III ст. н.е.; III-й період - класичний: IV - XII ст.); IV-й період - гатха-йогічний: XII - XV ст. [Данилов 2020: 10]².

Окресливши часові періоди становлення йоги й ті тексти, які до них належать, автор переходить до аналізу змістів і значень поняття дг'яна у відповідних першоджерелах. На його думку, поняття дг'яна формується у ведичний період. У «Ригведі» зустрічаються слова з коренем dhi, а саме: dhih, dhitih, dhiyā. Однозначного перекладу цих слів, згідно з автором, немає. Перші два він пропонує перекладати як «поетична інтуїція», «внутрішня сила бачення», або ж «думка породжена прозрінням». Третє як «джерело знань про ціле буття». Крім цих слів, зустрічається ще й dhitir, що українською можна перекласти, як «спрямованість думки до божества»; зустрічається також слово dhiyo, яке можна перекласти, як «візіонерське прозріння/осяяння». Звідси висновок автора про те, що корінь dhi та похідні від нього слова у «Ригведі» мають гносеологічне, тобто пізнавальне, значення, й позначують ментальні процеси (мислення, роздуми, думки), результатом яких є досягнення цілого буття, осягнення божественного, сакрального і трансцендентного.

До цього ж періоду автор відносить і Упанімади. В одній з Упанішад, а саме «Каушитака-упанішада», присутнє уявлення, але ще не поняття, про дг'яну як «невід'ємну частину розуму», котрий єднає всі життєві сили: дихання, мовлення, слух, зір. Тому, як зазначає автор, «життя неможливе без розуму й мислення, тобто дг’яни» [с. 56]. У «Чхандог'я-упанішаді» вже зустрічаємо певну ієрархію пізнавальних здатностей людини, яка складається з чітти (внутрішньо-індивідуальне усвідомлення комплексу психічних станів), дг'яни (мислення, котре спрямовує чітту до глибокого розуміння) і віджняни (стану глибокого й осмисленого розуміння, котре трансцендує наявне буденне знання). Правильне мислення дг'яна є необхідним для переходу в стан глибокого й усвідомленого розуміння. Але таке мислення не виникне без бажання пізнавати сакральне, божественне, трансцендентне. I тут автор монографії знову прослідковує зв’язок дг'яни з чимось, що перевершує ось-буття, перевершує наявне знання, перевершує буденне пізнання. Поштовхом до практикування дг'яни є внутрішнє відчуття спорідненості з Брагманом завдяки Атману, який знаходиться в серці людини. Тому дг'яна виникає з Атмана, або, як перекладають цей термін європейці, з душі.

2 Надалі посилання на рецензовану книгу подаватимуться у квадратових дужках скорочено: тільки номер сторінки після скорочення с., без прізвища автора й року видання. 
Ще можна подибати й інші значення дг’яни в різних Ведах. Автор акцентує увагу на таких: «прямий метод пізнання того, що приховане від ока»; «надзусилля, спрямоване на непроявлене, щоб останнє проявило свою суть»; «роздуми про Атмана й зосередженість на ньому в стані спрямованості зору всередину себе (самопізнання, яке $€$ пізнанням Атмана)»: у результаті цих роздумів виникає розрізнення я й Атмана, тоді Атман може бути впізнаний. Цікаво, що стан нерозпізнаності Атмана й ототожнення його з я називається «станом мороку».

Отже, в Упанішадах формується й викристалізовується поняття дг'яна та окреслюється його семантика в межах тих духовних практик, які спрямовані на встановлення зв'язку із сакрально-трансцендентним, тим, що перевершує буденне та звичайне сприйняття себе і світу [с. 64-69].

Тексти епічних творів «Магабгарати» та «Бгалавадгіти», які належать до другого, епічного, періоду, є основними для аналізу поняття дг’яна. У «Магабгараті» поняття дг'яна, згідно з автором, має декілька значень, а саме: 1) акт мислення, що спрямовується на пізнання причин явищ; 2) акт збирання в єдине ціле ментальної розпорошеності (розмаїтих думок), коли розум (свідомість) досягає максимальної «зібраності» 3 метою досягнення нірвани не в буддистському сенсі, а в сенсі досягнення ментального спокою, «штилю», «затишшя», можна навіть сказати, «несуперечності» думок, коли вони не конфліктують між собою, а утворюють «спокійну єдність»; 3) методика (конкретна цілеспрямована робота з мисленням чи свідомістю), за допомогою якої досягають Брагмана й Атмана: вона полягає в приборканні чуттєвості, подоланні розгубленості та розпорошеності, відвертанні від об'єктів зовнішнього світу.

Таким чином, у «Магабгараті» дг'яна є підготовкою до самадгі, тобто до «вищого стану самопізнання», в якому досягається безмежний спокій, безпристрасність, безсмертя, коли є усвідомлений своїм усвідомленням чистий Атман («чистий», тобто «без просторо-часових властивостей та характеристик», «безякісний», «не-емпіричний») [с. 82].

У «Бгагавадгіті», згідно з автором, дг'яна набуває чи не найважливішого значення для тих, хто практикує йогу. Звернення дг’яни до буденних об'єктів, «торкання їх», контакт із ними деструктивно відбивається на розумі, оскільки вони його «нівечать», занурюють у марноту, жадобу, у бажання володіти ними. Іншими словами, мислення, занурене в буденні чуттєві речі, втрачає зосередженість, здатність до пізнання суті, забарвлюється негативними емоціями, що порушує його стійкість, твердість у пізнанні суттєвого та вагомого для звільнення від страждань і перероджень. Тому, каже Крішна, такому стану мислення й розуму треба протиставити мислення й розум, що спрямовані до трансцендентного й долають чуттєву сферу об'єктів. Долання забезпечується дг'яною як зосередженістю на божестві, концентрацією на вищому, мета-чуттєвому. Розвернути мислення/розум у напрямі над-чуттєвого - необхідна умова звільнення, задля якого пізніше треба ще й постійно утримувати це мислення/розум у зосередженості на над-чуттєвому. Така зосередженість породжує відчуття неприв'язаності ${ }^{3}$ до результатів своєї діяльності. Тоді настає спокій, умиротворення, оскільки згасають бажання досягати результатів у своїй діяльності та володіти ними.

${ }^{3}$ Д. Данилов уживає поняття «відчуженість» [Данилов 2020: 97-98], яке має ідеологічно-юридичне семантичне навантаження й не дуже пасує для окреслення ставлення йогіна до результатів власної діяльності. Наприклад, відчуження майна це процес позбавлення когось права володіти 
Крім цього значення дг'яни в «Бгагавадгіті», автор вирізняє ще одне: здатність розрізняти нерозрізнене в стані невідання Атмана. Таке розрізнення езотеричне ${ }^{4}$, бо дг’яна є внутрішнім зосередженим поглядом всередину себе, а точніше - у серце, в якому знаходиться Атман. Необхідно досягнути постійності перебування в Атмані (серці) за допомогою дг’яни, тоді можливе звільнення від перероджень. Д. Данилов цитує місце з «Бгагавадгіти», де стверджується, що таке знання навіть того, хто живе як завгодно, позбавляє подальших перероджень [с. 100].

Класичний період представлений в рецензовані книзі «Йога-сутрою», мабуть, найвідомішим і найпопулярнішим твором давньоіндійського мудреця Патанджалі. У третьому розділі цього твору систематично розкривається смисл і значення дг’яни. Цікаво, що Патанджалі відносить дг’яну до «внутрішньої» частини йоги [с. 106]. Дг'яна розглядається як наступний етап після досягнення зосередженості (дгарани) на об'єкті внутрішньої трансцендентності (Атмані), а саме, як процес пізнання цього об'єкта; пізнавши цей своєрідний об'єкт, йогін досягає самадгі - стану осяяння, яке, згідно з Д. Даниловим, «відбувається в момент, коли безліч суджень синтезуються та народжують нове, більш складне розуміння сутності об'єкта» [с. 107]. Тому дг'яна розуміється, як неперервне й тривале мислення, сфокусоване на об'єкті внутрішньої трансиендентності, яке веде до вищого розуміння цього об'єкта у формі осяяння (самадгі).

I, нарешті, останній, четвертий, гатха-йогічний, період представлений у монографії Д. Данилова аналізом дг'яни в таких традиційних текстах гатха-йоги, як «Горакшашятаку», «Даттатрея-йога-шастра», «Аманаска-йога» та «Гатха-йога-прадипіка». Цей вид йоги, згідно з автором, засвідчує переорієнтацію дг'яни. Вона постає вже не суто ментальною практикою, розвитком вміння зосереджуватися, тобто збирати своє мислення в єдине ціле і спрямовувати його на внутрішню трансцендентність (дг'яна як «внутрішня йога»), а розвитком зосередженості на частинах зовнішнього тіла для досягнення того ж ефекту - осяяння (самадгі). На думку Д. Данилова, така переорієнтація пов’язана з «отілесненням йоги в період гатха-йогічних текстів» [с. 121] ${ }^{5}$. Така пе-

певними предметами, мати певну власність, і надання такого права комусь іншому. Маркс писав про «відчуження праці», коли людина із суб'єкта стає об'єктом праці, а результати ії праці привласнюють ті, хто надає їй роботу (капіталісти). У процесі ж практикування дг'яни з'являється стан усвідомленої неприв'язаності чи відстороненості від результатів діяльності.

${ }^{4}$ Езотеричне позначає те, що є внутрішнім, на відміну від екзотеричного, що позначає зовнішнє. Щоб зрозуміти значення езотеричного, можна звернутися до Св. Августина, який у своїй праці «Про істинну релігію» зазначає: «Не виходь поза себе; повернись до самого себе, адже істина перебуває у внутрішній людині» [Aurelius Augustinus: §39.72]. Це типовий «езотеризм» Св. Августина, який перегукується з «езотеризмом» Атмана як «внутрішньої, справжньої, людини». Тут варто згадати і Григорія Сковороду, який також $є$ «езотеристом», бо говорить про «внутрішню людину». Усі ці «езотеричні» поняття - Атман, внутрішня людина, душа - вказують на особливий простір усередині людини, на внутрішню трансцендентність.

${ }^{5}$ На нашу думку, такий «поворот» до тілесності дг’яни в гатха-йозі зумовлений тим, що сама гатхайога призначена для людей тілесно-орієнтованих, тобто таких, що постійно турбуються про своє тіло, ототожнюючись із ним як своєю сутністю. Наприклад, це можуть бути спортсмени, моделі, телеведучі, кінозірки та інші. Для таких тілоцентрованих людей легше зосередитися на якихось частинах свого тіла, наприклад, на кінчику носа, на точці між бровами, на правому чи лівому великому пальці ніг, ніж на «невидимому», на Атмані. Тут ми маємо справу з озовніш- 
реорієнтація не змінює мети гатхи-йоги. Остання, озброюючись психосоматичною технікою дг'яни, продовжує орієнтуватися на ту саму мету, що й усі інші йоги ${ }^{6}$, на звільнення від існування, звільнення від жаги бути та уникнення смерті.

За підсумками огляду монографії Д. Данилова, треба визнати, що автору вдалося деконструювати стереотип щодо йоги, який полягає в тому, що заняття йогою нібито ведуть до «отупіння», «заціпеніння», відсутності мислення, до якогось «ступору», «загальмованості». Дана монографія засвідчує протилежне, а саме: важливість мислення та розуму для духовного вдосконалення. Удосконалюючи свої мислення та розум (тобто вміючи зосереджуватися, збирати в єдине ціле свої думки задля подолання суперечностей), людина може не лише стати розумнішою. Спрямовуючи такі зосереджені мислення та розум у своє серце, вона може відкрити простір внутрішньої трансцендентності, де знаходиться найбільший ії скарб - Атман чи душа, реалізація яких дарує невимовне щастя й радість.

$€$ ще один стереотип, який панує щодо східної філософії: мовляв, вона не має чітко розробленого поняттєвого апарату, їй бракує аналітичності та строгості мислення. Семантичний і змістовий аналіз поняття дг’яни руйнує цей стереотип. Навпаки, східна філософія, представлена в монографії Д. Данилова філософією йоги, містить детальну концептуалізацію тих станів, яких досягає йогін під час духовних практик, грунтується на глибокій рефлексії над поняттями медитативного досвіду задля усунення суб'єктивізму.

Історична деконструкція поняття дг'яна полягає в «зніманні» історично-семантичних, інтерпретаційних, нашарувань з метою прояснення первинного значення поняття дг'яна. Після такої деконструкції, автор реконструював це поняття на основі описаного в першоджерелах змісту йогічно-медитативного (психологічного) досвіду, який це поняття означує. Завдяки такій реконструкції вдалося показати, що дг'яна це не досягнення розумом пасивного стану (споглядання), а його когнітивна дія в зосередженому стані. I тільки після досягнення такого стану можна здійснити перехід до стану самадгі (споглядання трансцендентного).

Цікавим є те, що такий деконструктивно-реконструктивний підхід виявив певну стадіальну завершеність дг'яни, після якої здійснюється перехід на вищий рівень йоги - самадгі. Тому можна говорити про динамічне відношення між завершеною стадією йоги і новою стадією йоги - між дг'яною і самадгі, між завершеним і новим (вищим) йогічним досвідом. Деконструкція і реконструкція поняття дг'яни дозволяє, на мій погляд, краще зрозуміти філософську й когнітивно-медитативну природу цього поняття та його зв'язок із медитативним досвідом.

Поєднання деконструкції та реконструкції семантики й (емпіричного) змісту понять $є$ доволі ефективним для досліджень з історії філософських понять та ідей як

ненням дг'яни. Тобто концентрація на об'єкті внутрішньої трансцендентності замінюється концентрацією на частинах зовнішнього тіла. I треба враховувати, що така зовнішня концентрація має і психічне значення, адже сприяє збиранню психічних феноменів, як от мислення, емоції тощо, в єдине ціле. Тілесно орієнтованим людям важко практикувати чисту дг'яну, тобто відірвану від тілесності й одразу спрямовану на трансцендентне. Для них зрозумілішою $є$ дг'яна як розвиток вміння зосереджуватися на якійсь частині тіла. Така дг'яна також володіє трансформаційною силою, а ії результат - звільнення від страждань і перероджень.

${ }^{6}$ Маються на увазі: карма-йога, тантра-йога, раджа-йога, бгахті-йога тощо. 
галузі історії філософії. Рецензована монографія, на прикладі одного поняття індійської філософії йоги, демонструє, як можна віднайти зрозуміле значення та виявити емпіричну сферу функціонування того чи іншого філософського поняття.

Насамкінець зазначу, що монографія Д. Данилова засвідчує появу в Україні новітніх індологічних систематичних досліджень у сфері історії ідей (понять), які розширюють наше знання про особливості індійської філософії, зокрема йоги та медитації. Також вони відкривають перспективи вивчення філософсько-духовної спадщини Індії через транскультурні й компаративні студії з європейської та індійської філософії.

\section{СПИСОК ЛІТЕРАТУРИ}

Данилов, Д. (2020). Трансформація поняття дг’яна у вченні йоги. Київ: Дух і Літера.

Aurelius Augustinus. (s.a.). De Vera Religione liber unus. http://www.augustinus.it/latino/vera religione/index.htm

Newcombe, S., \& O’Brien-Kop, K. (Eds.). (2020). Routledge Handbook of Yoga and Meditation Studies. London \& New York: Routledge. https://doi.org/10.4324/9781351050753

Raveh, D. (2016). Sütras, Stories and Yoga Philosophy. London \& New York: Routledge. https://doi.org/10.4324/9781315637846

Sarbacker, S.R. (2005). Samādhi. The Numinous and Cessative in Indo-Tibetan Yoga. New York: State University of New York Press.

Одержано 02.03.2021

\section{REFERENCES}

Aurelius Augustinus. (s.a.). De Vera Religione liber unus. http://www.augustinus.it/latino/vera_religione/index.htm

Danylov, D. (2020). Transformation of the Concept Dhyāna in Yoga's Teaching. [In Ukrainian]. Kyiv: Dukh and Litera.

Newcombe, S., \& O’Brien-Kop, K. (Eds.). (2020). Routledge Handbook of Yoga and Meditation Studies. London \& New York: Routledge. https://doi.org/10.4324/9781351050753

Raveh, D. (2016). Sütras, Stories and Yoga Philosophy. London \& New York: Routledge. https://doi.org/10.4324/9781315637846

Sarbacker, S.R. (2005). Samädhi. The Numinous and Cessative in Indo-Tibetan Yoga. New York: State University of New York Press.

Received 02.03.2021

\section{Ihor Karivets}

Deconstruction and Reconstruction of the Concept Dhyāna: Strategies and Perspectives. Danylov, D. (2020). Transformation of the Concept Dhyāna in Yoga's Teaching. [In Ukrainian]. Kyiv: Dukh and Litera.

Review of Danylov, D. (2020). Transformation of the Concept Dhyāna in Yoga's Teaching. [In Ukrainian]. Kyiv: Dukh and Litera. 


\section{Ігор Карівець}

Деконструкція та реконструкція поняття дг’яна: стратегії та перспективи. Данилов, Д. (2020). Трансформація поняття «дг'яна» у вченні йоги. Київ: Дух і Літера.

Огляд видання Данилов, Д. (2020). Трансформаџія поняття дг'яна у вченні йоги. Київ: Дух і Літера.

Ihor Karivets, Doctor of Science in Philosophy, Associate Professor, Head of the Department of Philosophy at Lviv Polytechnic National University.

Ігор Карівець, доктор філософських наук, дочент, завідувач кафедри філософії Національного університету «Львівська політехніка».

e-mail: sacre@ukr.net 